\title{
Cytotoxic effect of compounds isolated from Goniothalamus marcanii Craib stem barks
}

\author{
K. Thienthiti ${ }^{1}$, P. Tuchinda ${ }^{2}$, A. Wongnoppavich ${ }^{3}, N$. Anantachoke $^{1}$, N. Soonthornchareonnon ${ }^{1 *}$ \\ ${ }^{I}$ Department of Pharmacognosy, Faculty of Pharmacy, Mahidol University, Bangkok 10400, \\ Thailand; \\ ${ }^{2}$ Department of Chemistry, Faculty of Sciences, Mahidol University, Bangkok 10400, Thailand; \\ ${ }^{3}$ Department of Biochemistry, Faculty of Medicine, Chiang Mai University, Chiang Mai \\ 50200, Thailand;
}

\begin{abstract}
Goniothalamus marcanii Craib (synonym of Goniothalamus tamirensis Pierre ex Finet \& Gagnep), is locally known as Khao Lam in Thai. The previous study showed that the isolated compounds from stem barks exhibited high cytotoxicity to human tumor cell lines. The objective of the research was to investigate compounds which showed cytotoxic effect. Column chromatography was used for isolation. The structures of the compounds were investigated by spectroscopic methods. The bioactivity of the compounds was determined by SRB assay. The result showed that four compounds, a styryl-lactone:(+)-goniodiol (1); and three alkaloids: ouregidione (2); noraristolodione (3); velutinam (4) were isolated from G. marcanii stem barks. Compound 3 possessed the strongest activity $\left(\mathrm{EC}_{50}\right.$ 35.56 and $50.75 \mu \mathrm{M}$ ), for A549 (lung) cells and HeLa (cervix) cells, respectively. Compound 1-3 displayed cytotoxic activity but less than that of doxorubicin, a conventional chemotherapeutic drug, the $\mathrm{EC}_{50}$ levels of which were 0.13 and $0.12 \mu \mathrm{M}$ for A549 and HeLa cells, respectively. On the other hand, compound 2 and 4 which could be evaluated from selective index values (SI 1.25 and 1.70, respectively) showed lower toxicity towards normal cells (MRC5) than doxorubicin (SI $=1.07$ ). From this study, G. marcanii stem barks found to be a new source of compounds 1-4. In addition, the investigation of compound 3 in cytotoxic activity and the evaluation of compounds 1 and 2 for cytotoxic activity to HeLa cell line have been reported for the first time.
\end{abstract}

Keyword: Goniothalamus marcanii/Cytotoxic/(+)-goniodiol/ouregidione/noraristolodione/velutinam

\section{INTRODUCTION}

The genus Goniothalamus (Blume) Hook. \& \& Thomson belongs to the Annonaceae family. This genus is particularly interesting in the field of oncology. According to this species have a broad array of secondary metabolites, which isabundantin annonaceous acetogenins ${ }^{1}$, styryl-lactones ${ }^{2}$, alkaloids ${ }^{3}$, and flavonoids ${ }^{4}$. Goniothalamus marcanii Craib (synonym of Goniothalamus tamirensis Pierre ex Finet \& Gagnep), locally known as Khao Lam, grows widely in the northern, northeastern and southern parts of Thailand. Its bark has a brown color with a few scattered lenticels. In Thailand, herbalists use this plant for infectious diseases in early childhood (under 5 years old) 5 . The previous studies reported that the extract from stem barks showed a cytotoxicity against human tumor cell lines, A-549, HT-29, MCF7, RPMI, and U251 with the $\mathrm{EC}_{50}$ in the range of $4 \times 10^{0}-1 \times 10^{2}$ $\mu \mathrm{g} / \mathrm{mL}$. Theextractcontained 1 -azaanthraquinone and naphthoquinone derivatives which possessed the high cytotoxicity against human tumor cell lines in the range of 0.04-3.03 $\mu \mathrm{M}^{6}$. Moreover, styryl-lactone and alkaloid compounds, isolated from other plants in this family also shown cytotoxic activity ${ }^{7,8}$. Thus, these finding compounds show a good opportunity to obtain new chemotherapeutic agents from $G$. marcanii stem barks in other fractions which also exhibited high cytotoxicity.

The present study aims to evaluate the in vitro cytotoxic activity of the isolated compounds from G. marcanii against human carcinoma cell lines, and to identify the components which may be responsible for the cytotoxic activity. 


\section{MATERIALS AND METHODS}

\subsection{Materials}

The UV spectra were obtained on a UV-2600 Shimuzu ${ }^{\circledR}$ spectrophotometer. The IR spectra were analysed on a Nicolet ${ }^{\mathrm{TM}}$ iS $^{\mathrm{TM}} 10$ infrared spectrometer, using potassium bromide disks and attenuated total reflectance method. High resolution mass spectra, liquid chromatography mass spectra, and Electron Impact mass spectra were examined on a micrOTOF Bruker ${ }^{\circledR}$, LCMS-8030 Shimadzu ${ }^{\circledR}$, and Polaris Q Thermoquest Finnigan ${ }^{\circledR}$, respectively. NMR spectra were recorded on an Avance Bruker ${ }^{\circledR}$. The optical rotation was determined on a Polax-2L ${ }^{\circledR}$. Silica gels 60 were purchased from Merck Co., Ltd, Germany. Dichloromethane, methanol, ethyl acetate, hexane, and acetic acid were purchased from Sigma-Aldrich Co., Ltd, USA. Silica gels P60 were purchased from Silicycle Inc, Canada. All chemicals and reagents were analytical grades. Tris (hydroxymethyl) aminomethane with molecular biology grade was purchased from Pacific Science Co., Ltd, USA. Trichloroacetic acid was purchased from VWR Co., Ltd, USA. Sulforhodamine B and doxorubicin were purchased from Sigma-Aldrich Co., Ltd, USA. Dulbecco's Modified Eagle Medium, $10 \% \mathrm{v} / \mathrm{v}$ foetal bovine serum and RPMI-1640 medium were purchased from Thermo Fisher Scientific Inc, USA. MRC-5, A549, and HeLa cell lines were purchased from American Type Culture Collection (ATCC), USA.

\subsection{Plant material}

The stem barks of $G$. marcanii were collected from Nakhonphanom, a province in the north-east of Thailand, in October 2014. The specimen was identified by Prof. Wongsatit Chuakul, Ph.D., Department of Pharmaceutical Botany, Faculty of Pharmacy, Mahidol University. The voucher specimen (PBM no. 05183) has been deposited at the Pharmaceutical Botany, Mahidol University Herbarium, Faculty of Pharmacy, Mahidol University, Thailand.

\subsection{Extraction and Isolation}

The ethanolic extract (F001) of the stem bark (3.3 kg, dry weight) was partitioned using a mixture of $\mathrm{CH}_{2} \mathrm{Cl}_{2}-\mathrm{H}_{2} \mathrm{O}(1: 1)$. The $\mathrm{CH}_{2} \mathrm{Cl}_{2}$ fraction (F003, $92.4 \mathrm{~g})$ was further partitioned between hexane-90\% aqueous $\mathrm{MeOH}(1: 1)$. The $90 \% \mathrm{MeOH}$ fractions (F006, $72.4 \mathrm{~g}$ ) gave the strongest bioactive fraction in brine shrimp test $\left(\mathrm{LC}_{50} 3.08 \mu \mathrm{g} / \mathrm{ml}\right)^{9}$. This fraction (F006) was adsorbed onto $150 \mathrm{~g}$ of kieselguhr and fractionated by a quick column chromatographic technique using a sintered glass filter column of silica gel $(800 \mathrm{~g}, 20 \times 10 \mathrm{~cm})$. A gradient of hexane $/ \mathrm{CH}_{2} \mathrm{Cl}_{2} / \mathrm{EtOAc} / \mathrm{MeOH}$ was collected and then combined according to their TLC patterns to obtain eleven fractions (F008-018). Then, all fractions were testified by brine shrimp lethality test. The fractions (F008-018) showed cytotoxic activity in different concentration. The fraction F015 (23.5 g) which was the most bioactive fraction in the BST $\left(\mathrm{LC}_{50} 0.98 \mu \mathrm{g} / \mathrm{ml}\right)$, was subjected to open Si-gel column chromatography (70-230 mesh) and eluted with a gradient of hexane $/ \mathrm{CH}_{2} \mathrm{Cl}_{2} / \mathrm{EtOAc} / \mathrm{MeOH}$ with increasing polarity. All fractions were collected and then combined according to their TLC patterns to obtain eleven fractions (F019-029). Then, all fractions were testified by brine shrimp lethality test and SRB assay. F023-025 showed a highly bioactive fraction in the cytotoxic test. Fraction F024 could be precipitated in EtOAc and F023 could be precipitated in $\mathrm{CH}_{2} \mathrm{Cl}_{2}$ : EtOAc (80:20) which gave an orange and yellow compounds. However, fraction F025 had neither an orange compound nor a yellow compound when examined under UV 365 nm. Fractions F026027 appeared only tailing dark spot when examined under UV $254 \mathrm{~nm}$. The precipitate of fraction (F024, $0.54 \mathrm{~g}$ ) was fractioned with a step gradient elution of $2.5 \% \mathrm{MeOH} / \mathrm{CH}_{2} \mathrm{Cl}_{2}$ to afford three compounds (compound $1,<1 \mathrm{mg}$, compound 2, $14.9 \mathrm{mg}$, compound 3, $11.6 \mathrm{mg}$ ). Then, all compounds were testified by SRB assay. The fraction (F023, $0.48 \mathrm{~g}$ ) was fractioned with a step gradient elution of $2.5 \% \mathrm{MeOH} /$ $\mathrm{CH}_{2} \mathrm{Cl}_{2}$ to afford the same compound (compound $1,16.0 \mathrm{mg}$ ) and another compound (compound 4, $42.0 \mathrm{mg}$ ). Then, all compounds were testified by SRB assay. The fractions (F023-F024) and eluted compounds showed a high polarity when compared to the 1-azaanthraquinone and 
naphthoquinone derivatives in TLC system. Then, all compounds were identified by spectroscopic methods.

\subsection{Structural Identification}

Compound 1: (+)-goniodiol

Appearance: Orange amorphous

Molecular formula: $\mathrm{C}_{13} \mathrm{H}_{14} \mathrm{O}_{4}$

UV $\lambda_{\max } n \mathrm{~nm}(\log \varepsilon): 242$ (3.38), 275 (3.44),

302 (3.48), 314 (3.50), and 440 (3.64)

IR $v_{\max } \mathrm{cm}^{-1}: 3412,2924,1720,1254$, and 1080

LCMS (I \%) $m / z: 234.30$ (100)

Optical rotation: $[\alpha]+7.2^{\circ}\left(c=0.3, \mathrm{CHCl}_{3}\right)$

${ }^{1} \mathrm{H}$ NMR: $400 \mathrm{MHz}$ and ${ }^{13} \mathrm{C}$ NMR: $100 \mathrm{MHz}$ in $\mathrm{CDCl}_{3}$ : Data were shown in Table 1 and 2; Figure 1

Compound 2: ouregidione_

Appearance: Yellow crystals

Molecular formula: $\mathrm{C}_{19} \mathrm{H}_{15} \mathrm{NO}_{5}$

UV $\lambda_{\max }$ nm (log $\left.\varepsilon\right): 242$ (3.38), 272 (3.43),

305 (3.48), 317 (3.50), and 421 (3.62)

IR $v_{\text {max }} \mathrm{cm}^{-1}: 3438,2923,1686,1621$, and 1390

Mass Spectrum EI-MS (rel. int.) $m / z: 337$ (9.7), 336 (42.0), 322 (26.1), 321 (100), 308 (5.5), and 294 (6.3)

ESI-MS (I\%) $m / z: 360.0853[\mathrm{M}+\mathrm{Na}]^{+}(100)$

${ }^{1} \mathrm{H}$ NMR: $500 \mathrm{MHz}$ and ${ }^{13} \mathrm{C}$ NMR: $125 \mathrm{MHz}$ in $\mathrm{CDCl}_{3}$ : Data were shown in Table 1 and 2; Figure 2

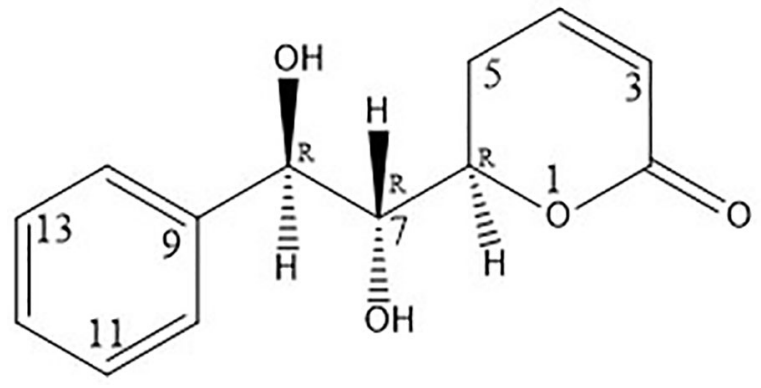

Compound 3: noraristolodione

Appearance: Orange amorphous

Molecular formula: $\mathrm{C}_{17} \mathrm{H}_{11} \mathrm{NO}_{4}$

UV $\lambda_{\max }$ nm (log $\left.\varepsilon\right): 244$ (3.39), 274 (3.44), 301 (3.48), 314 (3.50), and 445 (3.65)

IR $v_{\max } \mathrm{cm}^{-1}: 3368,2923,2853,1684,1663$, and 1379

Mass Spectrum EI-MS (rel. int.) $m / z: 294$ (3.7), 256 (3.4), 220 (5.6), 185 (9.9), 179 (13.53), 178 (100), 161 (40.2), 149 (30.6), 133 (19.5), 121 (23.83), 97 (17.5), 95 (28.4), 81 (33.5), and 57 (25.9)

ESI-MS (I\%) m/z: $316.0582[\mathrm{M}+\mathrm{Na}]^{+}(100)$

${ }^{1} \mathrm{H}$ NMR: $500 \mathrm{MHz}$ and ${ }^{13} \mathrm{C}$ NMR: $125 \mathrm{MHz}$ in DMSO- $d_{6}$ : Data were shown in Table 1 and 2; Figure 3

Compound 4: velutinam

Appearance: Brownish-yellow amorphous

Molecular formula: $\mathrm{C}_{17} \mathrm{H}_{13} \mathrm{NO}_{4}$

$\mathrm{UV} \lambda_{\text {max }} \mathrm{nm}(\log \varepsilon): 245$ (3.39), 298 (3.47), and 405 (3.61)

IR $v_{\text {max }} \mathrm{cm}^{-1}: 3415,2923,1672$, and 1649

Mass Spectrum EI-MS m/z: 295 (20.3), 294 (100), 280 (16.1), 252 (57.6), 237 (13.07), and 209 (14.8)

ESI-MS (I\%) $m / z: 318.0748[\mathrm{M}+\mathrm{Na}]^{+}(77.5)$

${ }^{1} \mathrm{H}$ NMR: $500 \mathrm{MHz}$ and ${ }^{13} \mathrm{C}$ NMR: $100 \mathrm{MHz}$ in DMSO- $d_{6}$ : Data were shown in Table 1 and 2; Figure 4

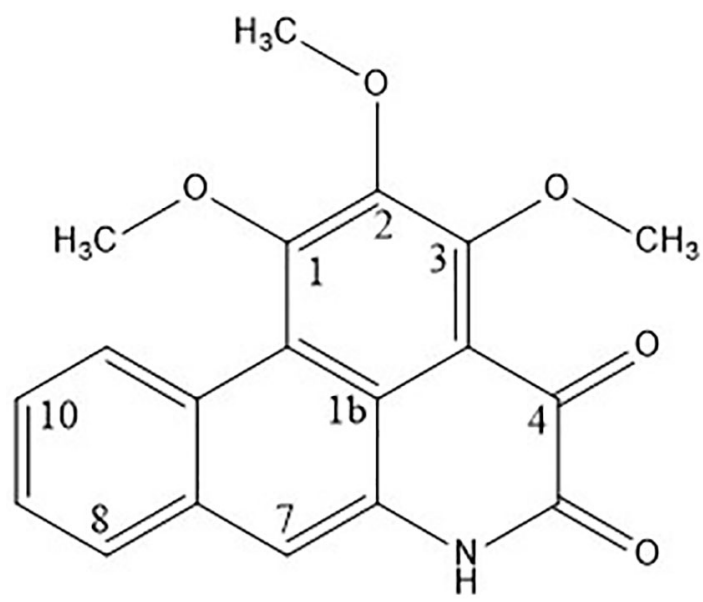



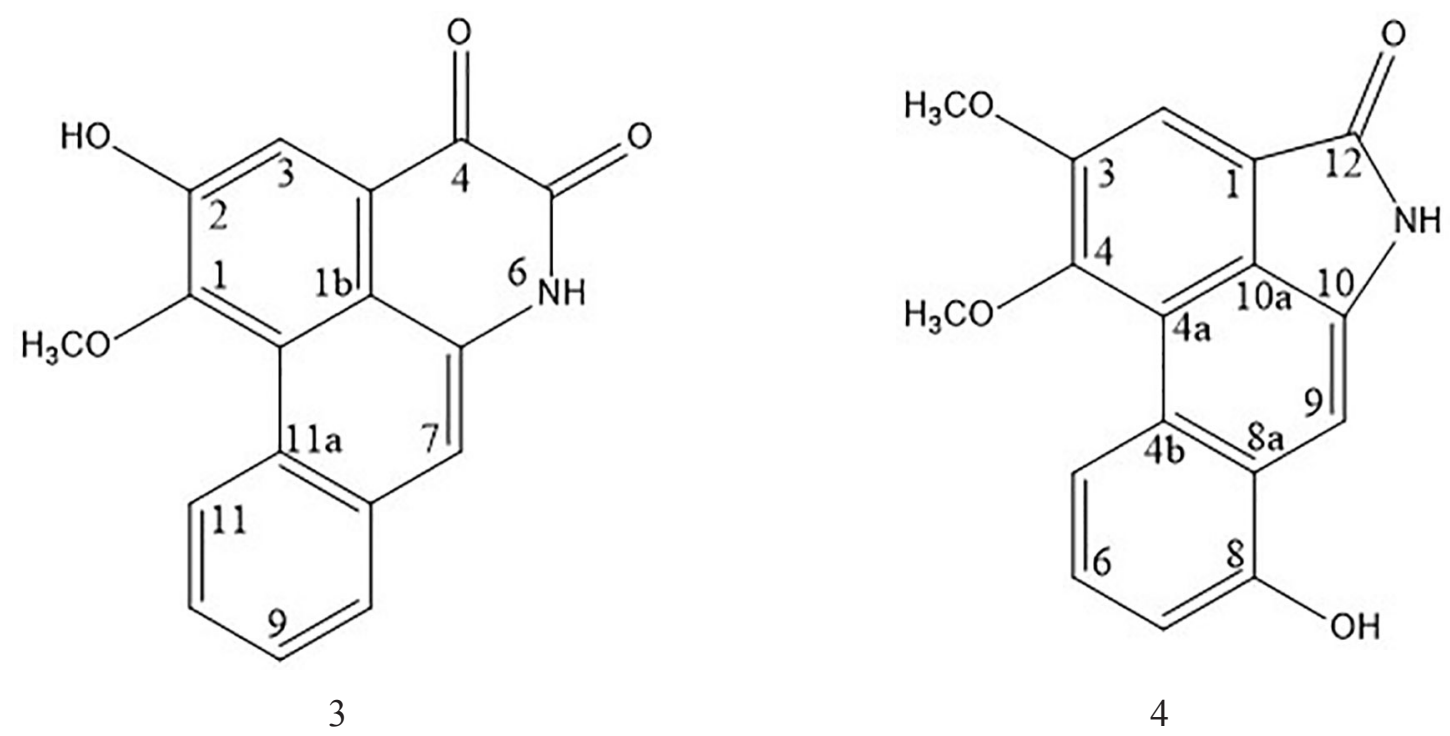

Table 1. ${ }^{1} \mathrm{H}$ assignments of compounds (+)-goniodiol and ouregidione in $\mathrm{CDCl}_{3}$ and noraristolodione and velutinam in DMSO- $\mathrm{d}_{6}$

\begin{tabular}{|c|c|c|c|c|}
\hline \multirow{2}{*}{ Position } & \multicolumn{4}{|c|}{$\delta{ }^{1} \mathrm{H}(\mathrm{ppm})$ multiplicities $(\mathrm{J}, \mathrm{Hz})$} \\
\hline & $(+)$-Goniodiol & Ouregidione & Noraristolodione & Velutinam \\
\hline 1 & - & - & - & - \\
\hline $1 \mathrm{a}$ & - & - & - & - \\
\hline $1 b$ & - & - & - & - \\
\hline 2 & - & - & - & $7.85(1 \mathrm{H}, s)$ \\
\hline 3 & $5.97(1 \mathrm{H}, d d, \mathrm{~J}=10.0,2.4)$ & - & $8.08(1 \mathrm{H}, s)$ & - \\
\hline $3 a$ & - & - & - & - \\
\hline 4 & $6.93(1 \mathrm{H},, d d d, \mathrm{~J}=9.6,6.4,2.0)$ & - & - & - \\
\hline $4 a$ & - & - & - & - \\
\hline $4 b$ & - & - & - & - \\
\hline 5 & $\begin{array}{l}2.19(1 \mathrm{H}, d d d, \mathrm{~J}=18.4,6.0,4.0) \\
2.78(1 \mathrm{H}, t d d, \mathrm{~J}=18.8,10.8,2.0)\end{array}$ & - & - & $8.62(1 \mathrm{H}, d, \mathrm{~J}=7.50)$ \\
\hline 6 & $4.78(1 \mathrm{H}, d d d, \mathrm{~J}=11.6,3.6,2.4)$ & $11.55(1 \mathrm{H}, s)$ & $12.04(1 \mathrm{H}, s)$ & $7.36(1 \mathrm{H}, t, \mathrm{~J}=8.0)$ \\
\hline $6 a$ & - & - & - & - \\
\hline 7 & $3.71(1 \mathrm{H}, d d, \mathrm{~J}=7.6,2.4)$ & $7.81(1 \mathrm{H}, s)$ & $7.48(1 \mathrm{H}, s)$ & $7.08(1 \mathrm{H}, d, \mathrm{~J}=7.7)$ \\
\hline $7 \mathrm{a}$ & - & - & - & - \\
\hline 8 & $4.93(1 \mathrm{H}, d, \mathrm{~J}=7.2)$ & $7.97(1 \mathrm{H}, m)$ & $7.92(1 \mathrm{H}, m)$ & - \\
\hline $8 \mathrm{a}$ & - & - & - & - \\
\hline 9 & - & $7.65(1 \mathrm{H}, m)$ & & $7.42(1 \mathrm{H}, s)$ \\
\hline 10 & 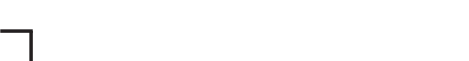 & $7.66(1 \mathrm{H}, m)$ & $7.61-7.66(2 \mathrm{H}, m)$ & - \\
\hline $10 \mathrm{a}$ & & - & - & - \\
\hline 11 & $-\quad 7.32-7.43(5 \mathrm{H}, m)$ & $9.50(1 \mathrm{H}, m)$ & $9.45(1 \mathrm{H}, m)$ & $10.81(1 \mathrm{H}, s)$ \\
\hline $11 \mathrm{a}$ & & - & - & - \\
\hline 12 & 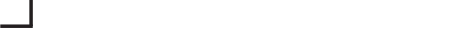 & - & - & - \\
\hline $1-\mathrm{OCH}_{3}$ & - & $4.17(3 \mathrm{H}, s)$ & $4.05(3 \mathrm{H}, s)$ & - \\
\hline $2-\mathrm{OCH}_{3}$ & - & $4.10(3 \mathrm{H}, s)$ & - & - \\
\hline $3-\mathrm{OCH}_{3}$ & - & $4.10(3 \mathrm{H}, s)$ & - & $4.05(3 \mathrm{H}, s)$ \\
\hline $4-\mathrm{OCH}_{3}$ & - & - & - & $4.01(3 \mathrm{H}, s)$ \\
\hline $2-\mathrm{OH}$ & - & - & $10.84(1 \mathrm{H}, s)$ & - \\
\hline $8-\mathrm{OH}$ & - & - & - & $10.17(1 \mathrm{H}, s)$ \\
\hline $7,8-\mathrm{OH}$ & $2.57(s), 3.05(s)$ & - & - & - \\
\hline
\end{tabular}


Table 2. ${ }^{13} \mathrm{C}$ assignments of compounds (+)-goniodiol and ouregidione in $\mathrm{CDCl}_{3}$ and noraristolodione and velutinam in DMSO- $d_{6}$

\begin{tabular}{|c|c|c|c|c|}
\hline \multirow{2}{*}{ Position } & \multicolumn{4}{|c|}{$\delta^{13} \mathrm{C}(\mathrm{ppm})$} \\
\hline & $(+)$-Goniodiol & Ouregidione & Noraristolodione & Velutinam \\
\hline 1 & - & 157.5 & 153.3 & 123.8 \\
\hline $1 \mathrm{a}$ & - & 121.2 & 124.5 & - \\
\hline $1 b$ & - & 120.2 & 117.7 & - \\
\hline 2 & 163.8 & 147.5 & 151.5 & 110.3 \\
\hline 3 & 120.5 & 158.6 & 117.5 & 154.6 \\
\hline $3 a$ & - & 117.6 & 125.2 & - \\
\hline 4 & 146.2 & 175.3 & 177.4 & 151.0 \\
\hline $4 a$ & - & - & - & 120.6 \\
\hline $4 b$ & - & - & - & 127.5 \\
\hline 5 & 26.0 & 160.4 & 156.1 & 118.3 \\
\hline 6 & 76.8 & - & - & 126.2 \\
\hline $6 a$ & - & 128.3 & 130.7 & - \\
\hline 7 & 75.0 & 115.9 & 112.5 & 112.6 \\
\hline $7 a$ & - & 131.7 & 132.9 & - \\
\hline 8 & 73.6 & 128.4 & 128.8 & 154.2 \\
\hline $8 \mathrm{a}$ & - & - & - & 124.4 \\
\hline 9 & 140.8 & 127.5 & 128.3 & 99.3 \\
\hline 10 & 128.2 & 127.4 & 127.1 & 134.3 \\
\hline $10 \mathrm{a}$ & - & - & - & 122.0 \\
\hline 11 & 128.7 & 127.2 & 127.6 & - \\
\hline 11a & - & 127.2 & 126.5 & - \\
\hline 12 & 126.6 & - & - & 168.8 \\
\hline 13 & 128.7 & - & - & - \\
\hline 14 & 128.2 & - & - & - \\
\hline $1-\mathrm{OCH}_{3}$ & - & 62.0 & 60.09 & - \\
\hline $2-\mathrm{OCH}_{3}$ & - & 61.7 & - & - \\
\hline $3-\mathrm{OCH}_{3}$ & - & 61.1 & - & 57.3 \\
\hline $4-\mathrm{OCH}_{3}$ & - & - & - & 60.3 \\
\hline
\end{tabular}

\subsection{Bioassay}

Brine shrimp lethality assay (BST): This assay was used for cytotoxicity-guided fractionation. The brine shrimp lethality bioassay is an efficient, rapid and inexpensive test that requires only a relatively small amount of sample (2-20 mg). This bioassay has a good correlation with cytotoxic activity in some human solid tumors and with pesticidal activity. About $2 \mathrm{mg}$ of each sample was accurately weighed and dissolved in $30 \mu \mathrm{l}$ of dimethyl sulfoxide (DMSO), then 1,570 $\mu 1$ of sea water was added. The solution obtained was diluted with sea water to get $1000,100,10$ and $1 \mu \mathrm{g} / \mathrm{mL}$ solutions. The final concentrations of DMSO in each test were $1.82,0.089,0.0043$, and $0.0002 \% \mathrm{v} / \mathrm{v}$. The negative control was DMSO in seawater. The $50 \mu 1$-portion of the suspension containing 4-8 
shrimps was pipetted and added to each well. The number of surviving was recorded after 24 hours. Using Probit analysis, the lethality concentration $\left(\mathrm{LC}_{50}\right)$ was assessed at $95 \%$ confidence intervals. $\mathrm{LC}_{50}$ was determined by plot dose response curve between; $\mathrm{Y}$ : The mean of percentage mortality; X: Concentrations ${ }^{9}$

Cytotoxicity assay: Cells are cultured in a microtitre well plate and the rate of multiplication and growth is measured indirectly by the formation of a color, the intensity of which is directly proportional to the number of cells present. The reason for using SRB assay because this assay exhibiting a number of advantages including sensitivity, simplicity, reproducibility and rapidity when compared to formazan-based assays. In addition, a stable end-point that does not require a time-sensitive measurement has set SRB assay more applicable than the MTT or XTT assays ${ }^{10}$. The human tumor cell lines utilized as the target cells in this test were shown in Table 3. Human tumor cell lines of the cancer screening panel were grown in RPMI 1640 medium. Cells were inoculated into 96well microtiter plates in $100 \mu 1$. The microtiter plates were incubated at $37^{\circ} \mathrm{C}, 5 \% \mathrm{CO}_{2}, 95 \%$ air and $100 \%$ relative humidity for $24 \mathrm{~h}$. With 10 -fold serial dilution, the ranges of final concentrations in the wells were 100 to 0.01 $\mu \mathrm{g} / \mathrm{mL}$ for the extracts and 100 to $0.01 \mathrm{ng} / \mathrm{mL}$ for the compounds. Doxorubicin was used as a positive control. Then, each concentrations $(100 \mu 1)$ of the test sample in culture medium were added to the wells containing the cells. Medium (100 $\mu$ l) only was added to the control wells. The cells with the samples were incubated at $37{ }^{\circ} \mathrm{C}, 5 \% \mathrm{CO}_{2}, 95 \%$ air and $100 \%$ relative humidity for $48 \mathrm{~h}$. For adherent cells, the assay was terminated by the addition of cold TCA. Cells were fixed in situ by the gentle addition of cold $50 \%(\mathrm{w} / \mathrm{v})$ TCA $(50 \mu \mathrm{l})$ (final concentration, 10\% TCA). Sulforhodamine B (SRB) solution $(100 \mu \mathrm{l})$ at $0.4 \%(\mathrm{w} / \mathrm{v})$ in $1 \%$ acetic acid was added to each wells, and plates were incubated for 10-30 minutes at room temperature. After staining unbound dye was removed by washing with $1 \%$ acetic acid. The bound stain was subsequently solubilized with $10 \mathrm{mM}$ Trizma base $(100 \mu \mathrm{l})$ and the absorbance was read on an automated plate reader at a wavelength of $515 \mathrm{~nm}$. The optical density (OD) of SRB in each wells were directly proportional to the cell number so the OD values can be plotted against concentration and the $\mathrm{EC}_{50}$ determined by plot dose response curve between Y: Percent of control cell growth $=[$ (mean OD test - mean OD day0) / (mean OD negative count - mean OD day0)] $\times 100 ; \mathrm{X}$ : Concentrations ${ }^{11}$

Table 3. The plating densities of individual cell lines

\begin{tabular}{ccc}
\hline MRC5 & Normal lung cells & 20,000 cells/well \\
\hline A549 & Human lung carcinoma cells & 7,500 cells $/$ well \\
HeLa & Human cervical cancer cells & 5,000 cells/well \\
\hline
\end{tabular}

Selectivity index $(\mathrm{SI})=\mathrm{EC}_{50}$ of pure compound in normal cell line/EC $\mathrm{C}_{50}$ of pure compound in cancer cell line

As the value of SI demonstrates the differential activity of a compound, the greater the index value, the better it was. An SI value less than 2.0 indicates the general toxicity of the compound ${ }^{12}$.

\subsection{Statistical analysis}

All calculations have been done using
Microsoft Excel and SPSS statistics 17.0 analyze program. The comparisons have been done using One-Way ANOVA. All values were expressed as mean \pm SD. Statistical significances were tested. Differences were considered statistically significant when $p<0.05$.

\section{RESULTS AND DISCUSSION}

The structures of the isolated compounds were identified by spectroscopic methods. Comparisons of compound 1-4 with the literature 
data ${ }^{13-16}$ were performed. G. marcanii stem barks found to be a new source of compounds 1-4. Compound 1 had a styryl-lactone structure showing cytotoxicity against human tumor cell lines HL-60 (human promyelocytic leukemia cells) ${ }^{17}$ and P-388 (murine leukemia cells) ${ }^{18}$ and exhibited strong in vitro antimalarial activity against Plasmodium falciparum with $\mathrm{EC}_{50}$ values of $3.28 \mu \mathrm{g} / \mathrm{mL}^{19}$. This compound was found in Goniothalamus giganteus ${ }^{11}$ and Goniothalamus maewongensis ${ }^{20}$. Compound 2, one of aporphine alkaloids, possessed a wide array of biological activities such as the reduction of the oxidative stress burden ${ }^{21}$, cytotoxic activity toward hepatocellular carcinoma cells, breast cancer cells, and small cell lung cancer with being able to stimulate lymphocyte proliferation ${ }^{22,23}$ and antiproliferative activity in erythroleukemic, promonocytic, and promyelocytic leukemic cell lines. This compound was isolated from Pseuduvaria monticola ${ }^{21}$ and Pseuduvaria rugosa ${ }^{24}$. Compound 3 is also a type of aporphine alkaloids. This compound was isolated from Fissistigma balansae and Fissistigma oldhamii. It was reported to have antiplatelet aggregation property. Compound 4 was also isolated from
Fissistigma balansae and Fissistigma oldhamii. The compound belonged to aristololactams, showed strong inhibition of platelet aggregation induced by collagen ${ }^{25}$ and exhibited cytotoxicity against human epidermoid carcinoma (KB), human breast adenocarcinoma (MCF7), human small cell lung cancer (NCI-H187) and Vero cells. The compound exhibited strong in vitro antimalarial activity against $P$. falciparum with $\mathrm{EC}_{50}$ values of $5.89 \mu \mathrm{g} / \mathrm{mL}$ but inactive in antimycobacterial activity against Mycobacterium tuberculosis ${ }^{19}$. Moreover, the previous study showed selectively active against Gram-positive bacteria, but was weakly cytotoxic against HeLa (human cervical carcinoma), L1210 (murine leukaemia) cell lines ${ }^{16}$. Compound 4 showed the strongest inhibition of CDK1/cyclin B activity with $\mathrm{EC}_{50}$ values of $1.5 \mu \mathrm{M}$ and inhibition of DYRK1A activity with $\mathrm{EC}_{50}$ values of $0.6 \mu \mathrm{M}^{26}$. The isolated compounds from $G$. marcanii were evaluated for cytotoxic activity against normal lung fibroblast (MRC5), adenocarcinoma nonsmall cell lung epithelial (A549), and epitheloid cervix carcinoma (HeLa) cell lines. The results of bioactivity tests on compounds were shown in Table 4.

Table 4. Cytotoxic activity of compounds

\begin{tabular}{ccccc}
\hline \multirow{2}{*}{ Compound } & \multicolumn{4}{c}{ Cytotoxicity $(\mathrm{EC50}$ in $\mu \mathrm{M})$ in tumor cell lines } \\
\cline { 2 - 5 } & MRC5 & A549 & HeLa & Selectivity index (SI) \\
\hline (+)-Goniodiol (1) & $37.96 \pm 2.42$ & $159.16 \pm 8.16$ & $60.57 \pm 2.34$ & 0.63 \\
Ouregidione (2) & $73.09 \pm 7.12$ & $58.58 \pm 3.35^{*}$ & $67.77 \pm 1.86$ & 1.25 \\
Noraristolodione (3) & $37.54 \pm 4.91$ & $35.56 \pm 0.99$ & $50.75 \pm 2.18$ & 1.06 \\
Velutinam (4) & $306.98 \pm 5.12$ & $180.64 \pm 19.72^{*}$ & $455.12 \pm 7.29$ & 1.70 \\
Doxorubicin & 0.14 & 0.13 & 0.12 & 1.07 \\
\hline
\end{tabular}

A pure compound was considered inactive when $\mathrm{EC}_{50}$ is over than $100 \mu \mathrm{M}^{28}$.

*, $\mathrm{EC}_{50}$ is significantly difference when compared with normal cells (MRC5) / only lower than MRC5; $p$-value $<0.05$.

Compound 1 exhibited weakly cytotoxic activity against $\mathrm{HeLa}$ with $\mathrm{EC}_{50}$ value 60.57 $\mu \mathrm{M}$ and exhibited moderately cytotoxic activity against MRC5 but was inactive in A549 cells. Compound 2 was weakly cytotoxic against MRC5, A549, and HeLa (EC : $_{50}$ 58.58-73.09 $\mu \mathrm{M})$ but exhibited significant difference when compared tumor cells (A549) with normal cells (MRC5). Compound 3 exhibited the strongest cytotoxic activity against A549 and HeLa with $\mathrm{EC}_{50}$ values 35.56 and $50.75 \mu \mathrm{M}$, respectively. The compound 3 exhibited a moderate cytotoxic activity against MRC5. Compound 4 was inactive toward all cell lines but exhibited 
significant difference when compared tumor cells (A549) with normal cells (MRC5).

Compound 1-3 displayed cytotoxic activity but less than that of doxorubicin; a conventional chemotherapeutic drug, the $\mathrm{EC}_{50}$ levels of which were $0.14,0.13$, and $0.12 \mu \mathrm{M}$ for MRC5, A549, and HeLa cells, respectively. On the other hand, compound 2 showed a selective index value $(\mathrm{SI}=1.25)$ greater than doxorubicin $(\mathrm{SI}=1.07)$. Besides, the fractionated extracts displayed better cytotoxic activity than the pure compounds, as shown in Table 5. The fractionated extract (F024), having $\mathrm{EC}_{50}$ values in the range of $12.40-13.37 \mu \mathrm{g} / \mathrm{mL}$, could be classified as highly cytotoxic activity against the selected human tumor cell lines and moderate effect against normal cell line MRC5 $\left(\mathrm{EC}_{50}\right.$ values of $24.85 \mu \mathrm{g} / \mathrm{mL}$ ). Based on the above findings, some synergistic or antagonistic effects needed to be clarified. Combinations of cytotoxic agents require lower doses of each agents to obtain better therapeutic effects with less side-effect and toxicity ${ }^{27}$. Moreover, the active pure compound may not be eluted yet. Thus, the study may be worth further investigation with a view for isolating the active compounds.

Table 5. Cytotoxic activity of fractions

\begin{tabular}{ccccc}
\hline \multirow{2}{*}{ Fraction } & \multicolumn{4}{c}{ Cytotoxicity $\left(\mathrm{EC}_{50}\right.$ in $\left.\mu \mathrm{g} / \mathrm{ml}\right)$ in tumor cell lines } \\
\cline { 2 - 5 } & MRC5 & A549 & HeLa & Selectivity index (SI) \\
\hline F023 & $30.2 \pm 2.77$ & $7.82 \pm 0.14^{*}$ & $35.84 \pm 3.89$ & 3.86 \\
F024 & $24.85 \pm 1.96$ & $12.40 \pm 2.09^{*}$ & $13.37 \pm 0.83^{*}$ & 2.00 \\
\hline
\end{tabular}

A fitted dose-response curve were plotted to enable the calculation of the concentrations that kill $50 \%$ of the cells $\left(\mathrm{EC}_{50}\right)$. The criteria used were as follows: $\mathrm{EC}_{50}<20 \mu \mathrm{g} / \mathrm{ml}$ (high cytotoxic activity), $\mathrm{EC}_{50}: 20-100 \mu \mathrm{g} / \mathrm{ml}$ (moderate cytotoxic activity), $\mathrm{EC}_{50}: 201-500 \mu \mathrm{g} / \mathrm{ml}$ (weak cytotoxic activity), $\mathrm{EC}_{50}>500 \mu \mathrm{g} / \mathrm{ml}$ (no cytotoxic activity) ${ }^{29}$.

", $\mathrm{EC}_{50}$ is significantly difference when compared with normal cells (MRC5) / only lower than MRC5; $p$-value $<0.05$.

\section{CONCLUSION}

From the previous study, the stem bark extracts of Goniothalamus marcanii Craib were highly cytotoxic to the human tumor cell lines. Large-scale extraction of stem barks by solvent partitioning, and fractionation by chromatography on silica yielded three groups of cytotoxic compounds. One styryl-lactone, (+)-goniodiol (1), was obtained together with two known aporphine alkaloids, ouregidione (2), noraristolodione (3), and one known aristolactam velutinam (4). The isolated compounds showed the cytotoxic activity against human tumor cell lines in the range of 35.56-73.09 $\mu \mathrm{M}$. G. marcanii stem barks found to be a new source of compounds 1-4. In addition, the investigation of compound 3 in cytotoxic activity and the evaluation of compound 1 and 2 for cytotoxic activity to HeLa cell line have been reported for the first time.

\section{ACKNOWLEDGEMENT}

Authors are thankful to Faculty of Pharmacy, Mahidol University, Thailand for providing us facilities and financially support through this research. We also thank to Asst. Prof. Ariyapong Wongnoppavich, Ph.D. (Dpt. of Biochemistry, Faculty of Medicine, Chiang Mai University, Thailand) for providing SRB assay.

\section{REFERENCES}

1. Zeng L, Yan Z, McLaughlin JL. Gigantransenins A, B, and C, novel mono-THF acetogenins bearing trans double bonds from $G$. giganteus (Annonaceae). Tetrahedron Lett. 1996; 37:5449-52.

2. Jewers K, Davis JB, Dougan J, Manchanda AH, Blunden G, Aye K, et al. Goniothalamin and its distribution in four Goniothalamus species. Phytochemistry. 1972; 11(6):2025-30. 
3. Sheng-Teh L, Yang-Chang W, Shiow-Piaw L. Alkaloids of Formosan Fissistigma and Goniothalamus species. Phytochemistry. 1985; 24(8):1829-34.

4. Seidel S, Bailleul F, Waterman PG. (Rel)1b,2a-di-(2,4-dihydroxy-6-methoxybenzoyl)3b,4a-di-(4-methoxyphenyl)-cyclobutane and other flavonoids from the aerial parts of G. gardneri and G. thwaitesii. Phytochemistry. 2000; 55(5):439-46.

5. Mahiwan C, Buayairaksa M, Nuntasaen N, Meepowpan P, Pompimon W. Potential cancer chemopreventive activity of styryllactones from Goniothalamus marcanii. Am J Appl Sci. 2013; 10(1):112-16.

6. Soonthornchareonnon N, Suwanborirux K, Bavovada R, Patarapanich C, Cassady JM. New cytotoxic 1-azaanthraquinones and 3aminonaphthoquinone from the stem bark of G. marcanii. J Nat Prod. 1999; 62(10): 1390-4.

7. Abdullah N, Sahibul-Anwar H, Ideris S, Hasuda T, Hitotsuyanagi Y, Takeya K, et al. Goniolandrene A and B from Goniothalamus macrophyllus. Fitoterapia. 2013; 88:1-6.

8. Lekphrom R, Kanokmedhakul S, Kanokmedhakul K. Bioactive styryllactones and alkaloid from flowers of Goniothalamus laoticus. J Ethnopharmacol. 2009; 125(1): 47-50.

9. Meyer BN, Ferrigni NR, Putnam JE, Jacobsen LB, Nichols DE, McLaughlin JL. Brine shrimp: a convenient general bioassay for active plant constituents. Planta Med. 1982; 45(1):31-4.

10. Keepers YP, Pizao PE, Peters GJ, Ark-Otte JV, Winograd B, Pinedo HM. Comparison of the sulforhodamine-B protein and tetrazolium (MTT) assays for in vitro chemosensitivity testing. Eur J Cancer. 1991; 27(7):897-900.

11. Houghton P, Fang R, Techatanawat I, Steventon G, Hylands PJ, Lee CC. The sulphorhodamine (SRB) assay and other approaches to testing plant extracts and derived compounds for activities related to reputed anticancer activity. Methods. 2007; 42(4):377-87.
12. Badisa RB, Ayuk-Takem LT, Ikediobi CO, Walker EH. Selective anticancer activity of pure licamichauxiioic-B acid in cultured cell lines. Pharm Biol. 2006; 44(2):141-5.

13. Fang XP, Anderson JE, Chang CJ, Mclaughlin JL. Two new styryllactones, 9-deoxygoniopypyrone and 7-epigoniofufurone, from Goniothalamus giganteus. J Nat Prod. 1991; 54(4):1034-43.

14. Uadkla O, Yodkeeree S, Buayairaksa M, Meepowpan P, Nuntasaen N, Limtrakul P, et al. Antiproliferative effect of alkaloids via cell cycle arrest from Pseuduvaria rugosa. Pharm Biol. 2013; 51(3):400-4.

15. Priestap HA. Phenanthroid constituents from Aristolochia argentina. Biochem Syst Ecol. 2013; 46:83-7.

16. Omar S, Chee CL, Ahmad F, Ni JX, Jaber H, Huang J, et al. Phenanthrene lactams from Goniothalamus velutinus. Phytochemistry. 1992; 31(12):4395-7.

17. Nakashima K, Kikuchi N, Shirayama D, Miki T, Ando K, Sono M, et al. Total synthesis and cytotoxicity of (+)- and (-)goniodiol and 6-epi-goniodiol. Construction of $\alpha, \beta$-unsaturated lactones by ring-closing metathesis. Bull Chem Soc Jpn. 2007; 80 (2):387-94.

18. Prasad KR, Gholap SL. Facile stereoselective syntheses of goniodiol, 8-epi-goniodiol and 9-deoxygoniopypyrone. Tetrahedron Lett. 2007; 48(27):4679-82.

19. Suchaichita N, Kanokmedhakula K, Panthamab N, Poopasita K, Moosophona P, Kanokmedhakula S. A 2H-tetrahydropyran derivative and bioactive constituents from the bark of Goniothalamus elegants Ast. Fitoterapia. 2015; 103:206-12.

20. Pradupsri P, Loetchutinat C, Nuntasaen N, Meepowpan P, Tuntiwechapikul W, Pompimon W. Anticancer activities of styrylpyrone from the leaves and twigs of Goniothalamus maewongensis via cell cycle arrest. Am J Appl Sci. 2009; 6(12): 2018-23.

21. Taha H, Arya A, Paydar M, Looi CY, Wong WF, Murthy CRV, et al. Up-regulation of insulin secretion and down-regulation of pro-inflammatory cytokines, oxidative stress 
and hyperglycemia in STZ-nicotinamideinduced type 2 diabetic rats by Pseuduvaria monticola bark extract. Food Chem Toxicol. 2014; 66:295-306.

22. Sesang W, Punyanitya S, Pitchuanchom S, Udomputtimekakul P, Nuntasaen N, Banjerdpongchai $\mathrm{R}$, et al. Cytotoxic aporphine alkaloids from leaves and twigs of Pseuduvaria trimera (Craib). Molecules. 2014; 19(7):8762-72.

23. Wirasathien L, Boonarkart C, Pengsuparp T, Suttisri, R. Biological activities of alkaloids from Pseuduvaria setosa. Pharm Biol. 2006; 44(4):274-8.

24. Uadkla O, Yodkeeree S, Buayairaksa M, Meepowpan P, Nuntasaen N, Limtrakul P, et al. Antiproliferative effect of alkaloids via cell cycle arrest from Pseuduvaria rugosa. Pharm Biol. 2013; 51(3):400-4.

25. Chia YC, Chang FR, Teng CM, Wu YC. Aristolactams and dioxoaporphines from Fissistigma balansae and Fissistigma oldhamii. J Nat Prod. 2000; 63(8):1160-3.

26. Marti G, Eparvier V, Morleo B, Ven JL,
Apel C, Bodo B, et al. Natural aristolactams and aporphine alkaloids as inhibitors of CDK1/Cyclin B and DYRK1A. Molecules. 2013; 18:3018-27.

27. Breitinger HG. Drug Synergy-Mechanisms and Methods of Analysis. In: Acree B, editors. Toxicity and Drug Testing [Internet]. Shanghai: InTech China; 2012 Feb [cited 2016 Jun 15]:[about 25 p.]. Available from: http://www.intechopen.com/books/toxicityand-drug-testing/drug-synergy-mechanismsand-methods-of-analysis.

28. Boyd MR. The NCI in vitro anticancer drug discovery screen. In: Teicher BA, editors. Anticancer Drug Development Guide: Preclinical Screening, Clinical Trials, and Approval. New Jersey: Totowa; 1997. p. 23-42.

29. Geran RI, Greenberg NH, Macdonald MM, Shumacher AM, Abbott BJ. Protocols for screening chemical agents and natural products against animal tumors and other biological systems. Cancer Chemotherapy Reports, Part III. 1972; 3:1-103. 